\title{
Evaluating the Effect of Crude Oil Prices on Foreign Direct Investment: A Nigerian Perspective
}

\author{
Dr. Abbas Umar Ibrahim Nwoko Marshall Olakada* \\ Department of Business Administration, Nile University of Nigeria
}

\begin{abstract}
This research investigates the effect of the price of crude oil on foreign direct investment inflows to a country like Nigeria that produces the oil. We used secondary data on oil price and foreign direct investment inflows generated over a period of ten years from January 2010 to December 2019. The price per barrel of the Brent crude oil Nigeria's equivalent - is the independent variable, while quarterly aggregate foreign direct investment inflows to Nigeria is the dependent variable. We used the IBM Statistical Package for the Social Sciences (SPSS) to perform Simple Regression, Pearson, Kendall, Spearman's Correlation Coefficient, and Durbin Watson analyses of the independent and dependent variables. The output of the analysis revealed that there is a significant positive relationship between crude oil price and FDI inflows to Nigeria. A one dollar increase in the price of crude will cause a corresponding increase of $\$ 36.8 \mathrm{~m}$ in FDI inflow. We therefore inferred that investors are optimistic when the price of the commodity goes upward. Our recommendation is that governments of oil producing countries should take seriously anything that will bring about an increase in the price of crude oil. Since we used the aggregate quarterly FDI data in this research, there is need for researchers to isolate and use the FDI inflows that are targeted at the oil and gas industry to assess the extent of relationship in their future work.

Keywords: crude oil price, foreign direct investment, fluctuation of markets, investors sentiments, the oil industry.
\end{abstract} DOI: $10.7176 / \mathrm{EJBM} / 12-17-09$

Publication date:June 30th 2020

\section{Introduction}

Several studies have been carried out on different aspects of the crude oil market and investor sentiment. The multiplicity of studies buttresses the fact that the market has several parts. Gong, X., Wen, F., He, Z., Yang, J., Yang, X., and Pan, B., (2016) focused on extreme return, extreme volatility and investor sentiment where they concluded that except for extremely negative earnings, other return rate series significantly affect investor sentiment when they used the Ordinary Least Squares regression method to analyze them. But when they applied the Quartile Regression method, their conclusion was that both extremely positive and negative returns have their influences on pessimistic emotions, but volatility cannot impact on investor sentiment effectively and steadily.

On their own part, Ibrahim, U.A. and Mohammed, Z. (2020) while assessing the impact of Nigeria Capital Market on the Growth of the Banking Sector concluded that developments in the Nigerian capital market impact positively on the growth of the banking Sector. It is a well-known fact that crude oil is a major driver of the economies of almost all members of the Organization of Petroleum Exporting Countries (OPEC). That is why the industry is important to investors and governments around the world and any loss of attention to price changes in the industry will lead them into tribulations. Of concern to investors and these countries is the stability of the oil markets as it enables the oil producing countries and investors to be able to project into the future at least for planning purposes.

In their annual country report titled 'investment policy review in Nigeria', the United Nations Commission on Trade and Development (UNCTAD, 2009) posited that while Foreign Direct Investment (FDI) has been prominent in Nigeria's oil and gas development, it has remained low in other sectors and contributes little to their development. The report further stated that FDI inflows to Nigeria have been profoundly affected by the developments in the oil sector, its world price and Government policies in this area.

As a major oil producing country, Nigeria depends on revenue from oil to fund its budget, which is also influenced by the volume of oil it produces per day and the price prevailing at a given time. Most of these times, the prices of the commodity are hardly predictable. As Haider, A., Ahmed, Q.M., and Jawed, Z. (2014) put it, the history of energy prices has been characterized by extreme volatilities which makes forecasting and modelling of energy prices difficult. This year 2020, the country has had to change its revenue forecasts within the first quarter when it became clear that the earlier forecast based on a production output of 1.94 million barrels per day and a crude oil benchmark price of $\$ 57.00$ per barrel is not achievable as a result of the rapid decline in the price of crude oil to less than $\$ 20.00$ per barrel. The lowest price per barrel in more than eighteen years.

In the United States, investors in shale (a type of crude) oil production facilities rely greatly on the price of oil especially as the issue of breakeven point is important when they want to decide what new investments to make. Extreme fluctuations in the markets is therefore not something that bodes well for market decision makers.

Recently, rapid decline in the price of crude oil have been attributed to the effect of the COVID-19 Pandemic caused by the novel corona virus and responses of stakeholders on both the producing and importing sides in order 
to control the spread of the disease. Since investor sentiment is impacted by the outcome of market fluctuations in terms of volatility and return, how do investors react when the price of crude oil change?

\subsection{Statement of The Problem}

While we understand the effects of volatility of stock prices, their returns, and profits on investors sentiments, we need to explore avenues through which we can explain the role crude oil prices play in influencing the flow of FDI to a nation. This is especially important in the case of Nigeria where crude oil plays a dominant role in its economy.

Gong, X., Wen, F., He, Z., Yang, J., Yang, X. and Pan, B. (2016) in their research asserted that volatility cannot impact investor sentiment effectively and steadily because its explanatory power for investor sentiment is limited. On the other hand, the UNCTAD Investment Policy Review Nigeria Report (2009) says the correlation between the level of world oil prices and FDI inflows to Nigeria is particularly strong.

Based on these reports, we need to find out whether oil price changes can indeed affect FDI inflow and determine the extent of their relationship. This is pertinent because crude oil production is one in which Nigeria has a relatively competitive advantage among the comity of nations and it contributes more than fifty percent of its annual gross domestic product. So, a clear understanding of the influence of the price of crude oil on FDI flows into the country will enable the authorities to weigh the impact of their decisions aimed at influencing oil price in one direction or another.

\subsection{Research Objectives}

Our objectives in this paper are to:

i. $\quad$ To determine the relationship between crude oil price and aggregate foreign direct investment (FDI) inflows to a country that produces oil.

ii. To ascertain how crude oil price changes impact on foreign direct investment inflows to Nigeria.

iii. To determine the extent to which crude oil price volatility affect foreign direct investments inflows.

\subsection{Research Questions}

i. $\quad$ Is there any relationship between crude oil price and foreign direct investment (FDI) inflows?

ii. To what extent does crude oil price changes influence foreign direct investment (FDI) inflows?

iii. Does crude oil price volatility affect foreign direct investment (FDI) inflows?

\subsection{Research Hypotheses}

$\mathrm{H}_{01}$ : There is no significant relationship between crude oil market price and aggregate FDI inflows.

$\mathrm{H}_{02}$ : FDI is not affected by changes in crude oil prices.

$\mathrm{H}_{03}$ : There is no significant impact of crude oil market price volatility on FDI inflows.

This paper is composed of five sections as follows: Section one is the introduction, Section two reviews existing literature relating, Section three deals with methodology adopted, Section four is on results and findings, while we roundup with conclusions and recommendations.

\subsection{Literature Review}

Crude oil prices, market fluctuations, volatility, investors sentiments and FDI have been recognized by practitioners over the years by researchers who have tried to explain them. Their explanations become more significant when it is about crude oil, the most important middle investment resource in economic activity (Yang, T., Chou, C., Yang, Y. and Nguyen, N.P. 2018) and its price. Akinrele, A. (2016) posited that although OPEC would not want to cause price spikes, their objective is to see a steady increase that would encourage medium to long term investments in the global oil sector so, from time to time they play with their production quota to influence the price.

The volatility of the crude oil price puts investors on their toes as any loss of attention to the market can spell doom for them. The fluctuations are not without causes, Salameh, M.G. (2015), writing on factors behind the steep decline in crude oil prices, them as a glut in the global oil market caused by rising US shale oil production, over production by members of OPEC, and a slowdown in China and European Union (EU) economic growth, aa fall in global oil demand and possible political collusion between Saudi Arabia and the United States against Iran and Russia. Furthermore, the lack of cooperation and fear of losing market share between Russia and Saudi Arabia on the need to reduce output to arrest the downward slide in price prolong the fall (Akinrele, A. 2016).

The fall of oil prices is not without its consequences as when oil prices fall, producers whether they are multinationals or not run into cash flow problems and will not be able to make planned investments in the highly capital intensive industry adding to the fact that they need to have some element of certainty about future prices before committing huge investments to exploration and production (Salameh, M.G., 2015). As Akinrele, A. (2016) says, the majority of IOCs operating in Nigeria have divested from some of their onshore assets partly in response to the same reasons, regulatory developments, economic incentives elsewhere, and a desire to reduce their risk 
exposure associated with onshore oil and gas operations. This go on to affect their future profits and dividends to their shareholders.

Also, the panic due to the COVID-19 pandemic has affected global oil prices to the extent that it dropped to less than \$20, something never imagined in 18 years (Sykes, J. 2020). This situation has resulted in a drop in the stock prices of companies in the industry and investors are both panicky and cautious because they do not know where it will end (Nasdaq 21 April 2020).

In situations like this, investors are most likely to anticipate further crises in the industry thereby putting their planned investments on hold. For Yang, T., Chou, C., Yang, Y., Nguyen, P.N. (2018) the rise and fall of the stock market can be used as an economic opportunity and index of the business cycle and the fluctuations of stock prices has a strong relationship with the performance of the macro-economy. And could lead to a spiraling effect that causes lack of money to invest in expansion of production facilities etc. The motivation to invest will be negatively affected by this fear and the lack of capital to invest. On the other hand, increased oil price and other good management practices affects positively the flow of investments (Caldecott, B., Holmes, I., Fruitage, L., Orozco, D., Tomlinson, S. (2018). Carefully watching the fluctuation of oil prices may offer an early glimpse into future market trends, thereby helping to reduce losses and create value.

Anochie, U.C., Ude, D.K., Mgbemena, O.O. (2015) say the World Bank classifies Foreign Direct Investment (FDI) as an investment made to acquire a lasting management interest (normally $10 \%$ of voting stock) in a firm or an enterprise operating in a country other than that of the investor's defined according to residency. Their objective being to acquire a lasting interest and effective control in the management of the enterprise in which direct investment takes place. The level of FDI into a country could indicate how investors perceive the suitability of the country for investment.

\subsection{Theoretical Literature}

Oil prices generally are dictated by the forces of demand and supply, while investments generally chase after profits. As Sykes, J. (2020) put it, the most obvious cause of the price instability are the supply and demand metrics which are captured daily as news items that could draw or repel investors from the stock and inform many board room decisions in favour of divesting or investing. Valenti, D., Manera, M., Sbuelz, A. (2018) in arriving at their conclusion during their research say the expected returns of crude oil futures investment represent simply bets because spot and roll returns follow an uncertain scenario.

Salameh, M.G. (2015) wrote that the global economy cannot reconcile itself with low oil prices because it would undermine its main players which are: global investments, the oil industry, and the economies of the oil producing countries. In addition to that, the oil majors need high prices to be able to balance their books. On price predictability, he asserted that it is the hardest thing to predict because "there are so many conflicting cross currents that affect it". As Caldecott, B., Holmes, I., Fruitage, L., Orozco, D., Tomlinson, S. (2018) stated, the combination of an increased oil price and significant cost cutting by the IOCs meant that net investment within the IOCs increased.

Moosa, I.A., (2002) says FDI can be classified from several perspectives: the source and the host country; from the perspective of the investor, horizontal, vertical and conglomerate. Tumala, M.M., Ajibola, O.I., Omotosho, B.S., Baruwa, O.A. (2012) in their survey returns showed that total foreign claims on the Nigerian economy (liabilities) as at end 2011 rose to N12,729.69 billion from N11,681.32 billion recorded in 2010. They explained further that a breakdown of the figures showed that 74.8 per cent came in the form of direct investment, while portfolio investment and other capital flows accounted for 10.3 and 14.9 per cent, respectively.

\subsection{Empirical Literature}

In the empirical literature, sentiment has been measured using several approaches. One approach is to directly measure market sentiments by asking investors to show how optimistic they are and what are their expectations for the future market condition. This approach is generally conducted by utilizing survey-based data like Survey of Consumers of the University of Michigan (Ling, D.C., Ooi, T.L., and Le, T.T.T., (2015).

Although these indicators are inevitably prone to measurement errors. Researchers who adopt them are confident because these measurements are highly consistent with one another, as evident from the significantly positive correlation among them (Greenwood, R., and Shleifer, A. (2014). Similarly, Lin (2015) used Johansen's co-integration test and Granger's cause and effect test to investigate the correlation among futures price, the electronics stock index of Taiwan, the Kosdaq composite index of Korea, and the Nasdaq composite index of the United States. The results showed a two-way influence in Nasdaq and a one-way influence in the other markets.

Ademakinwa, R.A. and Omokanmi, O.J. (2017) concluded in their research that though oil price shocks have a great influence on the level of domestic investment and FDI, which greatly influence the level of growth in the Nigerian economy, the contribution of oil price shocks to GDP did not translate to a proportionate increase in FDI. However, what we have not seen in the literatures is a measurement of the relationship between oil price and the general investment flow into a given economy. This research is designed to evaluate the impact of oil price on 
foreign direct investment in Nigeria where oil is a dominant source of revenue to the economy.

Mahmood, H., Tawfik, T., and Alkhateeb, Y. (2018) while investigating the FDI, Domestic Investment and oil price nexus in Saudi Arabia, used the ARDL methodology to analyze their data and concluded that economic growth showed positive but insignificant influence on the FDI inflows in both the long and short run analyses, while favourable market developments alongside rising oil price showed a positive impact on FDI inflows into the Kingdom.

\subsection{Methodology}

In this research we obtained secondary data on oil price and FDI inflows spanning a period of ten years from January 2010 to December 2019 from the Central Bank of Nigeria (CBN), Census and Economic Information Centre (CEICdata) and Organization of Petroleum Exporting Countries (OPEC). The oil price per barrel in US Dollars were organized into average quarterly prices per barrel giving a population size of 40, while the quarterly FDI aggregate inflow also gave a population size of 40 as dependent variable. Data analysis was performed with the aid of the IBM Statistical SPSS. Regression analysis was used because it is statistically suitable to determine the cause-effect relationship between the two variables.

Suitability of the data sets was confirmed by testing the behavior of the variables used with the aid of a scatter plot and a line of fit to give us an idea of the behavior of the variables as shown below in Figure 1.

\subsection{Findings and Discussions}

This research was designed to investigate the impact of crude oil price on foreign direct investment inflows to Nigeria. The IBM SPSS output is discussed as follows.

Table 1: Descriptive Statistics

\begin{tabular}{|l|r|r|c|}
\hline \multicolumn{4}{|c|}{ Descriptive Statistics } \\
\hline & \multicolumn{1}{|c|}{ Mean } & Std. Deviation & $\mathrm{N}$ \\
\hline Quarterly FDI (\$m) & 334.4050 & 187.81128 & 40 \\
\hline Average Price Per Barrel (\$) & 80.7663 & 26.94488 & 40 \\
\hline
\end{tabular}

\section{Summary of Statistics}

Table 1 shows that the mean of the quarterly aggregate FDI is $\$ 334.41 \mathrm{~m}$, while its standard deviation (SD) is $\$ 187.81 \mathrm{~m}$, while the mean of average quarterly oil price is $\$ 80.77$, and its SD is $\$ 26.94$. The SD shows the variability or spread of the both variables being analyzed, while the mean denotes the average price over the ten years under consideration.

\section{Table 2A: Pearson Correlation Table}

\begin{tabular}{|l|l|c|c|}
\hline \multicolumn{4}{|c|}{ Correlation Measures } \\
\hline \multirow{4}{*}{ Average price per barrel (\$) } & Pearson Correlation & Average price per barrel (\$) & Quarterly FDI (\$m) \\
\cline { 2 - 4 } & Sig. (2-tailed) & 1 & $.368^{*}$ \\
\cline { 2 - 4 } & $\mathrm{N}$ & 40 & .020 \\
\hline \multirow{2}{*}{ Quarterly FDI (\$m) } & Pearson Correlation & $.368^{*}$ & 40 \\
\cline { 2 - 4 } & Sig. (2-tailed) & .020 & 1 \\
\cline { 2 - 4 } & $\mathrm{N}$ & 40 & 40 \\
\hline
\end{tabular}

\section{Correlations}

The correlation tables show that there is significant relationship between oil price and FDI. Which means that changes in the FDI can well be explained by changes in the crude oil price (see Tables 2A-C). The Pearson correlation coefficients show that there is evidence to reject the null hypotheses as the standardized coefficient is 0.368 falling outside the acceptance region. Its positive value indicates that there is a significant proportional positive relationship. This relationship is also supported by the Kendall's tau-b of 0.259 and Spearman's rho of 0.368 to the effect that at 0.05 level of significance (2-tailed), there is a significant relationship. The Durbin Watson coefficient value of 1,751 falls within an acceptable limit as the rule of thumb is that test statistic values in the range of 1.5 to 2.5 are relatively normal. It means that there is no first order auto correlation in the data. 
Table 2B: Other Correlations Continued

\begin{tabular}{|c|c|c|c|c|}
\hline & & & $\begin{array}{c}\text { AVERAGE PRICE PER } \\
\text { BARREL }(\$)\end{array}$ & $\begin{array}{l}\text { QUARTERLY } \\
\text { FDI }(\$ \mathrm{~m}) \\
\end{array}$ \\
\hline \multirow[t]{6}{*}{$\begin{array}{l}\text { Kendall's } \\
\text { tau_b }\end{array}$} & \multirow[t]{3}{*}{$\begin{array}{lll}\text { Average } & \text { Price } & \text { Per } \\
\text { Barrel (\$) } & & \end{array}$} & $\begin{array}{l}\text { Correlation } \\
\text { Coefficient }\end{array}$ & 1.000 & $.259^{*}$ \\
\hline & & Sig. (2-tailed) & . & .019 \\
\hline & & $\mathrm{N}$ & 40 & 40 \\
\hline & \multirow[t]{3}{*}{ Quarterly FDI (\$m) } & $\begin{array}{l}\text { Correlation } \\
\text { Coefficient }\end{array}$ & $.259^{*}$ & 1.000 \\
\hline & & Sig. (2-tailed) & .019 & 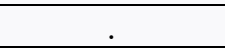 \\
\hline & & $\mathrm{N}$ & 40 & 40 \\
\hline \multirow[t]{6}{*}{$\begin{array}{l}\text { Spearman's } \\
\text { rho }\end{array}$} & \multirow[t]{3}{*}{$\begin{array}{lll}\text { Average } & \text { Price } & \text { Per } \\
\text { Barrel (\$) } & & \end{array}$} & $\begin{array}{l}\text { Correlation } \\
\text { Coefficient }\end{array}$ & 1.000 & $.382^{*}$ \\
\hline & & Sig. (2-tailed) & . & .015 \\
\hline & & $\mathrm{N}$ & 40 & 40 \\
\hline & \multirow[t]{3}{*}{ Quarterly FDI (\$m) } & $\begin{array}{l}\text { Correlation } \\
\text { Coefficient }\end{array}$ & $.382^{*}$ & 1.000 \\
\hline & & Sig. (2-tailed) & .015 & \\
\hline & & $\mathrm{N}$ & 40 & 40 \\
\hline
\end{tabular}

*. Correlation is significant at the 0.05 level (2-tailed).

Table 2C: Other Coefficients

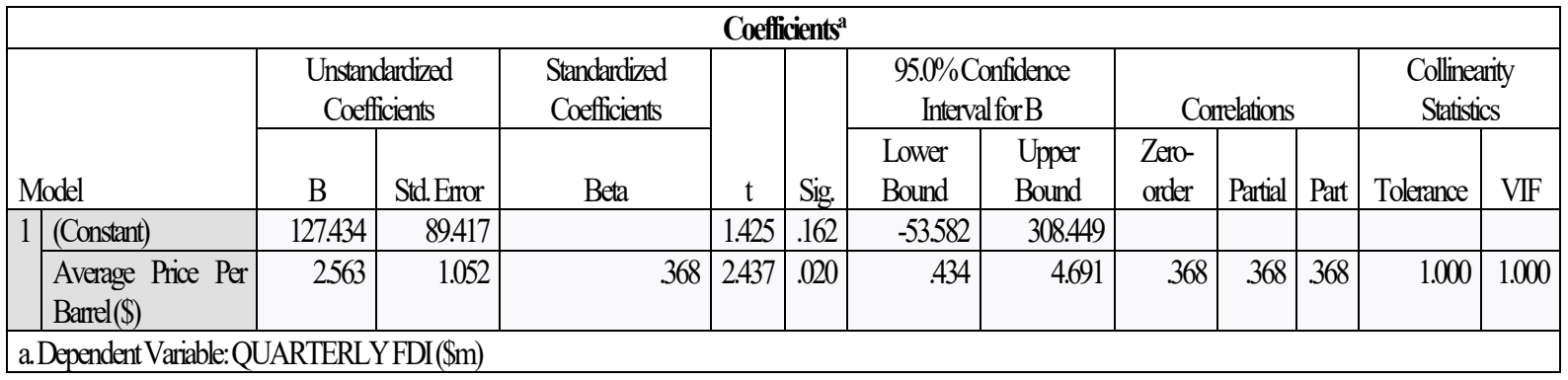

Table 3: Model Output Summary

\begin{tabular}{|c|c|c|c|c|c|c|c|c|c|c|}
\hline \multicolumn{11}{|c|}{ Model Summary $^{\mathbf{b}}$} \\
\hline \multirow[b]{2}{*}{ Model } & \multirow[b]{2}{*}{$\mathrm{R}$} & \multirow[b]{2}{*}{ R Square } & \multirow[b]{2}{*}{$\begin{array}{l}\text { Adjusted } \\
\text { R Square }\end{array}$} & \multirow[b]{2}{*}{$\begin{array}{l}\text { Std. Error of } \\
\text { the Estimate }\end{array}$} & \multicolumn{5}{|c|}{ Change Statistics } & \multirow[b]{2}{*}{$\begin{array}{l}\text { Durbin- } \\
\text { Watson }\end{array}$} \\
\hline & & & & & $\begin{array}{l}\text { R Square } \\
\text { Change }\end{array}$ & $\begin{array}{c}\mathrm{F} \\
\text { Change }\end{array}$ & df1 & $\mathrm{df} 2$ & $\begin{array}{c}\text { Sig. F } \\
\text { Change }\end{array}$ & \\
\hline 1 & $.368^{\mathrm{a}}$ & .135 & .112 & 176.94096 & .135 & 5.939 & 1 & 38 & .020 & 1.751 \\
\hline
\end{tabular}

\section{The Regression Model}

In Table 3, we can deduce a model for the relationship using a simple regression equation model of $\mathbf{Y}=\mathbf{a}+\mathbf{b} \boldsymbol{X}+$ e, where $\mathrm{Y}$ is the FDI, $X$ is the oil price per barrel, a is intercept, $b$ is slope of the line and e is error term. Substituting the SPSS model summary output into the equation, you have Quarterly FDI $=127.434+2.563 x+$ e. This can be used to predict the FDI based on a given of oil price. 
Table 4: Analysis of Variance

\begin{tabular}{|c|c|c|c|c|c|c|}
\hline \multicolumn{7}{|c|}{$\mathbf{A N O V A}^{\mathbf{a}}$} \\
\hline \multicolumn{2}{|c|}{ Model } & Sum of Squares & df & Mean Square & $\mathrm{F}$ & Sig. \\
\hline \multirow[t]{3}{*}{1} & Regression & 185942.041 & 1 & 185942.041 & 5.939 & $.020^{\mathrm{b}}$ \\
\hline & Residual & 1189707.985 & 38 & 31308.105 & & \\
\hline & Total & 1375650.026 & 39 & & & \\
\hline \multicolumn{7}{|c|}{ a. Dependent Variable: QUARTERLY FDI (\$m) } \\
\hline \multicolumn{7}{|c|}{ b. Predictors: (Constant), AVERAGE PRICE PER BARREL (\$) } \\
\hline
\end{tabular}

\section{The ANOVA}

In Table 4, the linear regression's F-test has the null hypothesis that there is no linear relationship between the two variables, meaning that $\mathrm{R}^{2}=0$. But with $\mathrm{F}=5.939$ and 39 degrees of freedom the test shows that there is significant linear relationship between the variables in our model.

Table 5: Collinearity Diagnostics

\begin{tabular}{|c|c|c|c|c|c|}
\hline \multicolumn{3}{|c|}{ Collinearity Diagnostics $^{\mathbf{a}}$} \\
\cline { 5 - 6 } Model & Dimension & Eigenvalue & Condition Index & (Constant) & Average Price per Barrel (\$) \\
\hline 1 & 1 & 1.950 & 1.000 & .03 & .03 \\
\cline { 2 - 6 } & 2 & .050 & 6.232 & .97 & .97 \\
\hline
\end{tabular}

\section{Collinearity Diagnostics}

From Table 5, the variation impact factor of 1.000 shows that the effect on the dependent variable are not inflated as the general rule of thumb is that VIFs exceeding 4 warrant further investigation, while VIFs exceeding 10 are signs of serious multicollinearity requiring correction

\section{Table 6: Residual Statistics}

\begin{tabular}{|l|r|r|r|r|r|}
\hline \multicolumn{7}{|c|}{ Residuals Statistics $^{\mathbf{a}}$} \\
\hline & \multicolumn{1}{|c|}{ Minimum } & \multicolumn{1}{c|}{ Maximum } & \multicolumn{1}{c|}{ Mean } & Std. Deviation & N \\
\hline Predicted Value & 212.9476 & 438.0973 & 334.4050 & 69.04886 & 40 \\
\hline Residual & -292.77826 & 460.27579 & .00000 & 174.65776 & 40 \\
\hline Std. Predicted Value & -1.759 & 1.502 & .000 & 1.000 & 40 \\
\hline Std. Residual & -1.655 & 2.601 & .000 & .987 & 40 \\
\hline a. Dependent Variable: QUARTERLY FDI (\$m)
\end{tabular}

The table 6 shows the minimum, maximum, mean and standard deviation of the predicted values as 212.9476, $438.0973,334.4050$ and 69.04886 respectively. While the residual statistics are $-292.77826,460.27579,0.0000$ and 174.65776. standard predicted values and residuals are also reflected of the table.

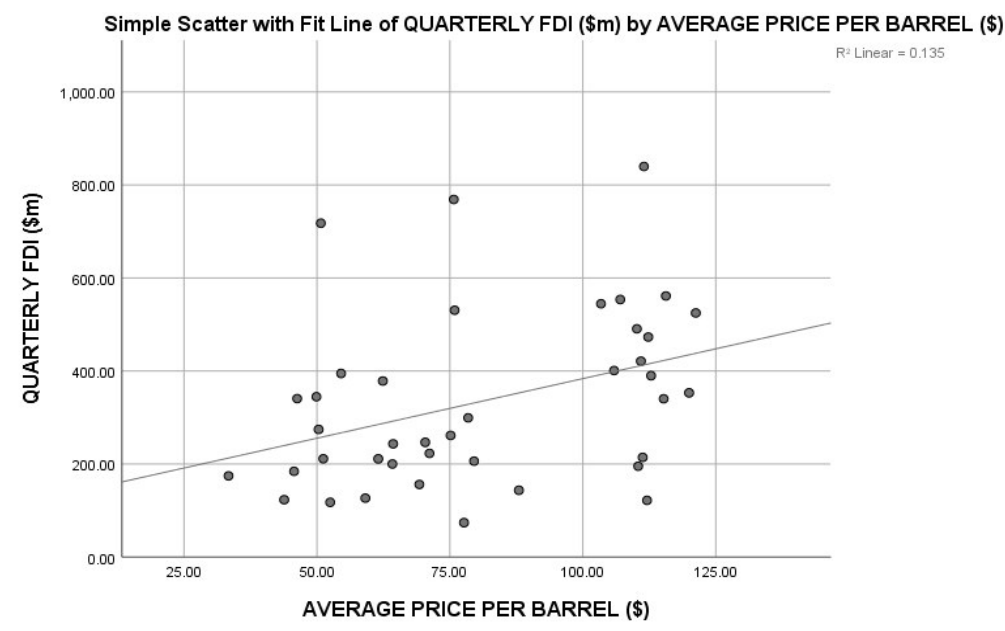

Figure 1: Simple Scatter with fit line of quarterly FDI 


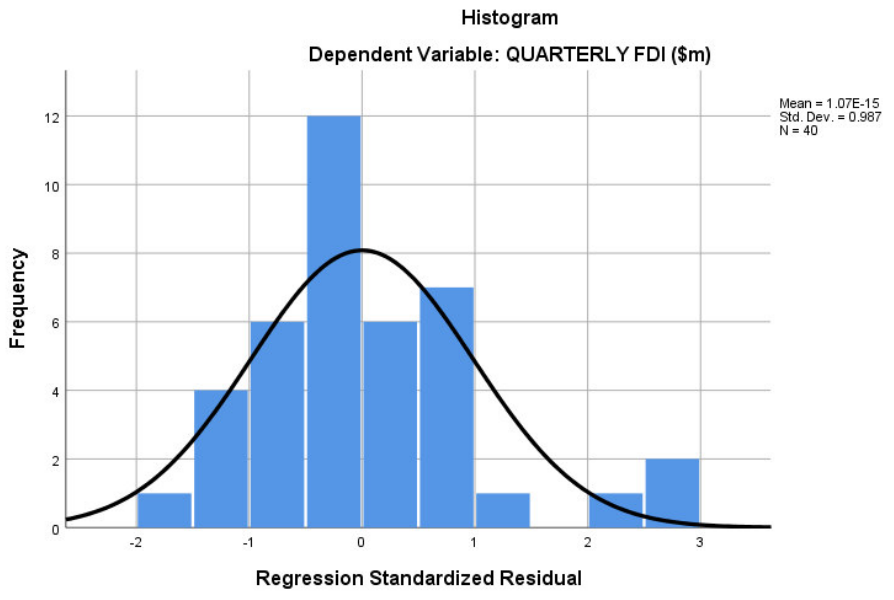

Figure2: Histogram and Regression Diagram

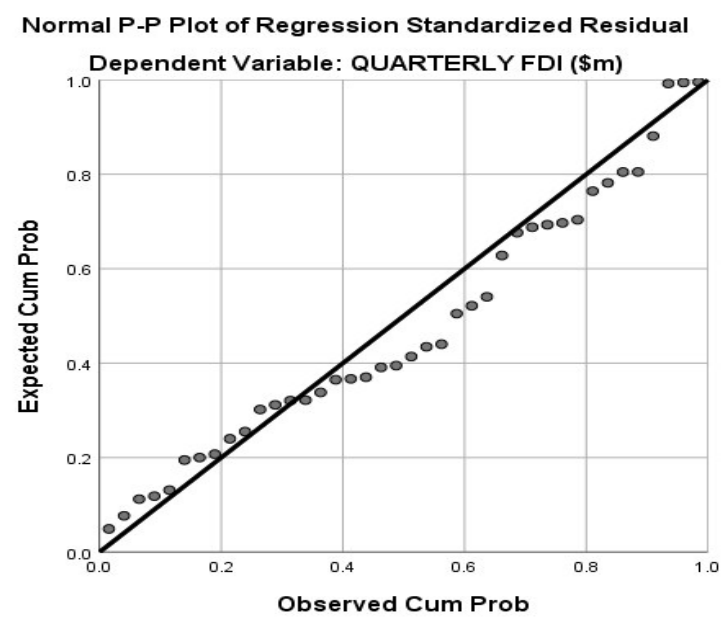

Figure 3: The P-P Plot

\subsection{Conclusion/Recommendations}

This research evaluated the effect of crude oil price on FDI from the Nigerian perspective. From the above discussions, we can conclude that our research questions have been answered to the effect that there is a significant relationship between crude oil price and FDI inflows and changes in crude oil prices affect (FDI) inflows. Foreign investors are optimistic when crude oil prices consistently go up, resulting into an increased FDI inflows into the oil exporting country. This in effect shows that forces that that influence the price of oil will also affect FDI inflows into the economy as is the case during this COVID-19 pandemic.

Drawing from the conclusions, the following recommendations are suggested:

i. Nigeria should always take seriously efforts that will increase the price of oil as it will not only affect positively the FDI inflows but will bring more money to the country.

ii. Since this research used aggregate foreign direct investment inflows to Nigeria as the dependent variable and the data was not restricted to only the FDI inflows to the oil industry, any future research in this area should use only the FDI inflows to the oil industry to see if the results will be different.

iii. Also, future research should investigate how much time lapses before foreign investors react to oil price changes.

\section{References}

Ibrahim, U.A., Mohammed, Z., (2020). Assessment of the Impact of Nigeria capital Market on the Growth of Banking Sector: A time Series Analysis for the Period 1998 - 2017 (20 Years). https://www.iosrjournals.org/e-ISSN: 2278-487X, P-issn:2319-7668.

Gong, X., Wen, F., He, Z., Yang, J., Yang, X., Pan, B., (2016). Extreme Return, Extreme Volatility and Investor Sentiment. https://www.jstor.org/stable/10.2307/24899482.

Yang, T., Chou, C., Yang, Y., Nguyen, P.N., (2018). Correlation among stocks of 28 major industries in Taiwan and prices of Dubai crude and Brent crude. (2018). https://www.jstor.org/stable/10.2307/26478035. 
Caldecott, B., Holmes, I., Fruitage, L., Orozco, D., Tomlinson, S. (2018). The crude awakening: making oil major business models climate compatible. https://www.jstor.org/stable/resrep17728.5

Salameh, M.G. (2015). Factors behind the steep decline in crude oil prices. Arab Center for Research and Policy Studies Workshop, November 2015. www.jstor.org/stable/resrep12701

Anochie, U.C., Ude, D.K., Mgbemena, O.O. (2015). Foreign Direct Investment (FDI) Flows in Nigeria: Pro or Economic Growth Averse? https://www.iosrjournals.org e-ISSN: 2321-5933, p-ISSN: 2321-5925

Valenti, D., Manera, M., Sbuelz, A. (2018). Interpreting the Oil Risk Premium: do Oil Price Shocks Matter? https://www.jstor.org/stable/resrep16428

Ademakinwa, R.A., Omokanmi, O.J. (2017) Oil Price Shocks and Foreign Direct Investment (FDI): Implications for Economic Growth in Nigeria (1980-2014). https://www.iiste.org/ISSN 2222-1700 (Paper) ISSN 22222855.

Akinrele, A (2016). The Current Impact of Global Crude Oil Prices on Nigeria - an Overview of the Nigerian Petroleum and Energy Sector. Journal of World Energy Law and Business, 9, 313-345, doi: 10.1093/jwelb/jww024.

Moosa, I. A (2002). Foreign Direct Investment: Theory, Evidence and Practice, Palgrave,

Tumala, M.M., Ajibola, O.I., Omotosho, B.S., Baruwa, O.A. (2012). Survey of Foreign Assets and Liabilities in Nigeria 2011 Report, CBN Journal of Applied Statistics Vol. 3 No. 2

Haider, A., Ahmed, Q., \& Jawed, Z. (2014). Determinants of Energy Inflation in Pakistan: An Empirical Analysis. The Pakistan Development Review, 53(4), 491-504. www.jstor.org/stable/24398734

Ling, D.C., Ooi, T.L., and Le, T.T.T., (2015) Explaining House Price Dynamics: Isolating the Role of Nonfundamentals, https://doi.org/10.1111/jmcb.12194

Greenwood, R., and Shleifer, A. (2014). "Expectations of Returns and Expected Returns.” Review of Financial Studies 27 (3): 714-746.

John Sykes Jr. (2020) https://www.arkansasonline.com/news/2020/mar/31/oil-prices-plummet-to-lowest-since$02-2 /$

Mahmood, H., Tawfik, T., and Alkhateeb, Y. (2018) Foreign Direct Investment, Domestic Investment and Oil Price Nexus in Saudi Arabia, International Journal of Energy Economics and Policy, 2018, 8(4), 1-5.

OECD. Benchmark Definition of Foreign Direct Investment. (2008) Fourth Edition, https://doi.org/10.1787/9789264045743-en

UNCTAD Investment Policy Review Nigeria. https://unctad.org/en/Docs/diaepcb20081_en.pdf 